\title{
FAKTOR-FAKTOR YANG MEMPEGARUHI PENDAPATAN PEDAGANG DI PASAR GULINGAN KECAMATAN MENGWI KABUPATEN BADUNG
}

\section{GUSTI AYU LIA YASMITA}

\author{
Fakultas Ekonomi Dan Bisnis Universitas Tabanan
}

liayasmita25@gmail.com

\begin{abstract}
ABSTRAK
Tujuan penelitian ini adalah untuk mengetahui pengaruh modal dan jam kerja baik secara parsial maupun simultan terhadap pendapatan pedagang di Pasar Gulingan Kecamatan Mengwi Kabupaten Badung. Penelitian ini dilakukan di Pasar Gulingan dengan jumlah sampel sebanyak 80 responden. Metode yang digunakan dalam penelitian ini adalah teknik sensus. Pengumpulan data dilakukan dengan metode wawancara, observasi dan dokumentasi. Teknik analisis data yang digunakan untuk memecahkan permasalahan dalam penelitian ini yaitu : 1) Uji Asumsi Klasik yang meliputi : Uji Multikolinieritas, Uji Heterokedastisitas dan Uji Autokorelasi. 2) Pengujian Hipotesis menggunakan Teknik Analisis Regresi Linier Berganda.

Hasil penelitian menunjukkan modal dan jam kerja secara simultan berpengaruh signifikan terhadap pendapatan pedagang di Pasar Gulingan Kecamatan Mengwi Kabupaten Badung. Modal dan jam kerja secara parsial berpengaruh positif dan signifikan terhadap pendapatan pedagang di Pasar Gulingan Kecamatan Mengwi Kabupaten Badung.
\end{abstract}

Kata kunci : Modal, Jam Kerja, Pendapatan

\begin{abstract}
The purpose of this study was to determine the effect of capital and working hours either partially or simultaneously on the income of traders in Gulingan Market, Mengwi District, Badung Regency. This research was conducted in Gulingan Market with a total sample of 80 respondents. The method used in this research is census technique. Data collection was carried out by interview, observation and documentation methods. The data analysis techniques used to solve the problems in this study were: 1) Classical Assumption Test which includes: Multicollinearity Test, Heteroscedasticity Test and Autocorrelation Test. 2) Hypothesis Testing using Multiple Linear Regression Analysis Techniques.

The results showed that capital and working hours simultaneously had a significant effect on the income of traders in Gulingan Market, Mengwi District, Badung Regency. Capital and working hours partially have a positive and significant effect on the income of traders in Gulingan Market, Mengwi District, Badung Regency.
\end{abstract}

Keywords: Capital, Working Hours, Income

\section{PENDAHULUAN}

Pasar tradisional merupakan pasar yang berperan penting dalam memajukan pertumbuhan ekonomi di Indonesia dan memiliki keunggulan bersaing secara alamiah (Chris, 2006). Keberadaan pasar tradisional ini sangat membantu, tidak hanya bagi pemerintah daerah ataupun pusat tetapi juga masyarakat yang menggantungkan hidupnya dalam kegiatan berdagang, karena di dalam pasar tradisional terdapat banyak aktor yang memiliki arti penting dan berusaha untuk mensejahterakan kehidupannya, baik itu pedagang, pembeli, pekerja panggul, dan sebagainya (Guna, 2015). Mereka semua adalah aktor yang berperan penting dalam mempertahankan eksistensi pasar tradisional di Indonesia (Ayuningsasi, 2013).

Pasar tradisional di Bali memiliki keunikan yang tidak dimiliki oleh pusat perbelanjaan modern ataupun pasar tradisional lain di daerah lainnya. Selain memasarkan barang kebutuhan sehari-hari seperti pada pasar lainnya, pasar tradisional di Bali juga memasarkan berbagai bahan-bahan kebutuhan upacara (Prathiwa, 2016). Masyarakat dari tingkat bawah sampai tingkat atas tentunya akan membeli produk 
kebutuhan upacara di pasar tradisional. Ini menunjukkan pasar tradisional di Bali memiliki pangsa pasar yang berbeda dengan pusat perbelanjaan modern. Perdagangan menjadi salah satu penopang perekonomian bagi orang yang terlibat di dalamnya. Pendapatan yang diperoleh pedagang berupa keuntungan digunakan untuk menambah modal atau dapat memenuhi kebutuhan sehari-hari (Sudrajat, 2014). Sesuai dengan konsep teori produksi pendapatan para pedagang dipengaruhi oleh modal dan jam kerja.

Memulai sebuah usaha berdagang, salah satu hal paling penting yang dibutuhkan adalah modal (Susila, 2014). Pengertian modal usaha menurut Kamus Besar Bahasa Indonesia dalam Nugraha (2011), modal usaha adalah uang yang dipakai sebagai pokok (induk) untuk berdagang, melepas uang, dan sebagainya; harta benda (uang, barang, dan sebagainya) yang dapat dipergunakan untuk menghasilkan sesuatu yang menambah kekayaan. Modal dalam pengertian ini dapat diinterpretasikan sebagai sejumlah uang yang digunakan dalam menjalankan kegiatan-kegiatan bisnis. Modal adalah semua bentuk kekayaan yang dapat digunakan langsung maupun tidak langsung dalam proses produksi untuk menambah output (Hentiani, 2011). Dalam penelitian ini modal yang dimaksud adalah modal awal dalam bentuk uang yang digunakan untuk membeli barang dagangan yang akan dijual kembali. Satuan modal awal yang dimaksud adalah rupiah. Namun seorang pedagang tidak hanya memerlukan modal untuk menjalani usahanya, masih ada beberapa faktor lain yang diperlukan.

Setelah usaha dimulai, yang diperlukan suatu usaha agar dapat berjalan lancar dan berkembang adalah pengelolaan yang baik. Salah satu faktor penting dalam mengelola suatu usaha adalah menentukan jam kerja. Jam kerja adalah banyaknya lama waktu kerja dalam sehari (Titin, 2014). Satuan variabel jam kerja adalah jam per hari. Jika ingin memperoleh pendapatan yang tinggi maka diperlukan jam kerja yang tinggi pula. Semakin lama jam kerja atau operasional sebuah kios di pasar maka akan semakin tinggi pula kesempatan untuk memperoleh pendapatan yang tinggi.

Kecamatan Mengwi adalah salah satu kecamatan yang ada di Kabupaten Badung memiliki beberapa pasar traditional yang masih melakukan aktivitas perdagangannya sampai saat ini, salah satunya adalah Pasar Gulingan. Pasar gulingan adalah pasar tradisional yang berlokasi di sebelah timur Obyek Wisata Taman Ayun. Pedagang di Pasar Gulingan dalam menjalankan usahanya, pedagang menempati los-los dan toko yang telah disediakan oleh kepala pasar dan jenis dagangan yang dijual juga beraneka ragam mulai dari kebutuhan sandang, dan pangan. Untuk lebih jelasnya pengelompokan pedagang di Pasar Gulingan dapat dilihat pada Tabel 1 sebagai berikut :

Tabel 1. Pengelompokan Pedagang di Pasar Gulingan Kecamatan Mengwi Kabupaten Badung

\begin{tabular}{clcc}
\hline No & Jenis Pedagang & Jumlah Kios & Presentase(\%) \\
\hline 1 & Kelontong & 7 & 8,75 \\
2 & Sayur-sayuran & 12 & 15,00 \\
3 & Pakaian & 5 & 6,25 \\
4 & Daging Ayam & 4 & 5,00 \\
5 & Daging babi & 3 & 3,75 \\
6 & Ikan & 3 & 3,75 \\
7 & Sembako & 6 & 7,50 \\
8 & Buah-buahan & 8 & 10,00 \\
9 & Canang & 15 & 18,75 \\
10 & Sarana upacara adat Bali & 6 & 7,50 \\
11 & Jajan bali & 4 & 5,00 \\
12 & Nasi & 2 & 2,50 \\
13 & Bumbu & 3 & 3,75 \\
14 & Perabotan & 2 & 2,50 \\
\hline \multicolumn{2}{c}{ Jumlah } & $\mathbf{8 0}$ & $\mathbf{1 0 0}$ \\
\hline
\end{tabular}

Sumber : Laporan Kepala Pasar Gulingan, 2020

Berdasarkan Tabel 1.1 data di Pasar Gulingan, Kecamatan Mengwi, Kabupaten Badung terdapat 2 jenis dagangan terbanyak yaitu pedagang canang sebanyak 15 pedagang, kemudian pedagang sayur-sayuran sebanyak 12 pedagang. Sedangkan jenis dagangan yang jumlahnya sedikit adalah dagang nasi dan perabotan yaitu masing-masing 2 pedagang.

Berdasarkan pengelompokan pedagang diatas, pendapatan yang mereka perolehpun berbeda-beda. Pendapatan merupakan seluruh penerimaan baik berupa uang maupun berupa barang yang berasal dari pihak lain maupun hasil industri yang dinilai atas dasar sejumlah uang dari harta yang berlaku saat itu. Pendapatan merupakan sumber penghasilan seseorang untuk memenuhi kebutuhan sehari - hari dan sangat penting artinya bagi kelangsungan hidup dan penghidupan seseorang secara langsung mau pun tidak lagsung (Suroto, 2011). Pendapatan biasanya digunakan untuk menentukan tingkat kesejahteraan, karena dengan adanya pendapatan, sesorang dapat memenuhi kebutuhan hidupnya sehari-hari. 


\section{Rumusan Masalah}

Berdasarkan latar belakang yang telah diuraikan di atas, maka rumusan masalah dalam penelitian ini adalah :

1. Apakah modal berpengaruh secara parsial terhadap pendapatan pedagang di Pasar Gulingan, Kecamatan Mengwi, Kabupaten Badung?

2. Apakah jam kerja berpengaruh secara parsial terhadap pendapatan pedagang di Pasar Gulingan, Kecamatan Mengwi, Kabupaten Badung?

3. Apakah modal dan jam kerja berpengaruh secara simultan terhadap pendapatan pedagang di Pasar Gulingan, Kecamatan Mengwi, Kabupaten Badung?

\section{Tujuan dan Manfaat Penelitian}

Berdasarkan rumusan masalah, maka tujuan dalam penelitian ini adalah untuk :

1. Mengetahui pengaruh modal secara parsial terhadap pendapatan pedagang di Pasar Gulingan, Kecamatan Mengwi, Kabupaten Badung.

2. Mengetahui pengaruh jam kerja secara parsial terhadap pendapatan pedagang di Pasar Gulingan, Kecamatan Mengwi, Kabupaten Badung.

3. Mengetahui pengaruh modal dan jam kerja secara simultan terhadap pendapatan pedagang di Pasar Gulingan, Kecamatan Mengwi, Kabupaten Badung.

Manfaat penelitian ini bagi pemerintah diharapkan mampu memberi masukan bagi pemerintah untuk memperhatikan dan mengambil suatu kebijakan yang berkaitan dengan keberadaan pedagang di Pasar Gulingan Kecamatan Mengwi serta diharapkan dengan adanya kebijakan tersebut, pemerintah dapat memonitoring jalannya kebijakan tersebut dan nantinya dapat dipantau seberapa besar tingkat efektifitas dari kebijakan tersebut.

\section{METODE PENELITIAN}

Penelitian ini merupakan penelitian eksperimen dengan populasi yaitu seluruh pedagang di Pasar Gulingan dan pemilihan sampel menggunakan teknik sampling jenuh yaitu teknik penentuan sampel bila semua anggota populasi digunakan sebagai sampel dan jenis data berupa data kuantitatif. Data Kuantitatif dalam penelitian ini yaitu hasil dari kuisioner yang sesuai dengan variabel yang akan diteliti. Data yang diperoleh berupa jawaban dari responden kemudian dianalisis menggunakan teknik analisis data regresi linier berganda dengan bantuam software SPSS.

\section{Hipotesis Penelitian}

Berdasarkan kerangka penelitian diatas, maka hipotesis yang diajukan dalam penelitian ini yaitu:

1. Modal secara parsial berpengaruh positif dan nyata terhadap pendapatan pedagang di Pasar Gulingan Kecamatan Mengwi Kabupaten Badung.

2. Jam kerja secara parsial berpengaruh positif dan nyata terhadap pendapatan pedagang di Pasar Gulingan Kecamatan Mengwi Kabupaten Badung.

3. Modal dan jam kerja berpengaruh nyata secara simultan terhadap pendapatan pedagang di Pasar Gulingan Kecamatan Mengwi Kabupaten Badung.

\section{Definisi Operasional}

Definisi operasional variabel diperlukan untuk mempertegas penafsiran variabel yang diteliti maka dikemukakan definisi operasional sebagai berikut :

1. Pendapatan $(\mathrm{Y})$ adalah jumlah penghasilan bersih yang diterima oleh pedagang yang dinyatakan dalam satuan rupiah.

2. Modal $\left(X_{1}\right)$ adalah jumlah uang yang digunakan oleh pedagang pada saat menjalankan usaha untuk membeli barang dagangannya yang akan dijual kembali, yang dinyatakan dalam satuan rupiah.

3. Jam kerja $\left(\mathrm{X}_{2}\right)$ adalah lamanya waktu dalam jam yang digunakan untuk bekerja dari seluruh pekerjaan, tidak termasuk jam kerja istirahat resmi dan jam kerja yang digunakan untuk hal-hal di luar pekerjaan. Jam kerja akan diukur menggunakan satuan jam/hari.

\section{HASIL DAN PEMBAHASAN}

Modal usaha yang dimaksud dalam penelitian ini adalah dana yang diperlukan oleh pedagang untuk memenuhi kebutuhan operasional usahanya sehari-hari, seperti pembelian bahan baku, pembayaran upah 
buruh, membayar hutang, membayar sewa dan pembayaran lainnya. Terdapat variasi besaran modal usaha antar pedagang karena perbedaan jenis barang yang dijual, sumber modal (sendiri/pinjaman) dan skala usahanya. Tabel berikut ini akan menunjukkan distribusi responden dilihat dari modal yang dimiliki.

Tabel 2. Jumlah Responden Pedagang di Pasar Gulingan Kecamatan Mengwi Kabupaten Badung Menurut Jumlah Modal

\begin{tabular}{clcc}
\hline No & \multicolumn{1}{c}{ Modal (Rp jt) } & Frekuensi (Orang) & Persentse (\%) \\
\hline 1 & $<5.000 .000$ & 51 & 63,75 \\
2 & $5.000 .000-10.000 .000$ & 20 & 25,00 \\
3 & $>10.000 .000$ & 9 & 11,25 \\
\hline & Jumlah & $\mathbf{8 0}$ & $\mathbf{1 0 0}$ \\
\hline
\end{tabular}

Sumber : Data Primer, 2020

Berdasarkan Tabel 2 di atas menunjukkan bahwa jumlah modal yang respondennya paling banyak terletak pada kelompok modal kurang dari Rp 5.000.000,00 dengan frekuensi sebanyak 51 responden (63,75 $\%$ ). Kemudian diikuti kelompok modal Rp 5.000.000,00 sampai Rp 10.000.000,00 dengan frekuensi sebanyak 20 responden $(25 \%)$. Kemudian frekuensi paling sedikit terletak pada kelompok modal di atas Rp 10.000.000,00 sebanyak 9 responden $(11,25 \%)$.

Jam kerja merupakan lamanya pedagang berjualan untuk menjual produknya. Besarnya pendapatan sangat ditentukan oleh berapa banyak waktu yang dicurahkan oleh pedagang untuk berjualan. Semakin tinggi curahan jam kerja akan semakin tinggi pula pendapatan yang diperoleh. Tabel berikut ini akan menunjukkan distribusi responden dilihat dari banyaknya jam kerja yang dicurahkan.

Tabel 3. Jumlah Responden Pedagang di Pasar Gulingan Kecamatan Mengwi Kabupaten Badung Menurut Jumlah Jam Kerja

\begin{tabular}{cccc}
\hline No & Jam Kerja (Jam) & Frekuensi (orang) & Persentase (\%) \\
\hline 1 & $<200$ & 13 & 16,25 \\
2 & $200-240$ & 11 & 13,75 \\
3 & $>240$ & 56 & 70,00 \\
\hline & Jumlah & $\mathbf{8 0}$ & $\mathbf{1 0 0}$ \\
\hline
\end{tabular}

Sumber : Data Primer, 2020

Berdasarkan Tabel 3 menunjukkan bahwa jumlah jam kerja yang respondennya paling banyak terletak pada kelompok responden di atas 240 jam kerja per bulannya dengan frekuensi sebanyak 56 responden (70 $\%)$. Kemudian diikuti kelompok kurang dari 200 jam kerja per bulannya dengan frekuensi sebanyak 13 responden $(16,25 \%)$. Kemudian frekuensi paling sedikit terletak pada kelompok 200 sampai dengan 240 jam kerja perbulannya sebanyak 11 responden $(13,75 \%)$.

Tujuan dijalankannya suatu usaha adalah memperoleh pendapatan. Pendapatan tersebut akan berpengaruh bagi kelangsungan usaha, dimana semakin besar pendapatan maka semakin besar pula kemampuan suatu usaha membiayai pengeluaran-pengeluaran. Tabel berikut ini menunjukkan distribusi responden dilihat dari rata-rata pendapatan yang diperoleh setiap bulannya.

Tabel 4. Jumlah Responden Pedagang di Pasar Gulingan Kecamatan Mengwi Kabupaten Badung Berdasarkan Pendapatan Perbulan

\begin{tabular}{clcc}
\hline No & \multicolumn{1}{c}{ Pendapatan $(\mathbf{R p} \mathbf{j t})$} & Frekuensi (orang) & Prosentase $(\boldsymbol{\%})$ \\
\hline 1 & $<5.000 .000$ & 59 & 73,75 \\
2 & $5.000 .000-10.000 .000$ & 16 & 20,00 \\
3 & $>10.000 .000$ & 5 & 6,25 \\
\hline & Jumlah & $\mathbf{8 0}$ & $\mathbf{1 0 0}$ \\
\hline
\end{tabular}

Sumber : Data Primer, 2020

Berdasarkan Tabel 4 di atas menunjukkan bahwa jumlah pendapatan pedagang yang respondennya paling banyak terletak pada kelompok pendapatan kurang dari Rp 5.000.000,00 dengan frekuensi sebanyak 59 responden (73,75\%). Kemudian diikuti kelompok pendapatan Rp 5.000.000,00 sampai Rp 10.000.000,00 dengan frekuensi sebanyak 16 responden (20\%). Kemudian frekuensi paling sedikit terletak pada kelompok pendapatan di atas Rp 10.000.000,00 sebanyak 5 responden $(6,25 \%)$.

\section{Hasil Uji Asumsi Klasik}

Uji asumsi klasik bertujuan agar hasil analisis regresi linier berganda memenuhi kriteria Best Linear Unbiased Estimator (BLUE) yaitu data terdistribusi normal, tidak terdapat gejala autokorelasi, tidak terdapat multikolinearitas, dan tidak bersifat heteroskedastis. Pengujian asumsi klasik ini meliputi uji 
multikolinieritas, uji heteroskedastis serta uji autokorelasi. Adapun pengujian yang dilakukan dalam uji asumsi klasik yaitu :

\section{Uji Multikolineritas}

Uji Multikolinearitas bertujuan untuk menguji apakah model regresi ditemukan adanya kolerasi diantara variable bebas (Independen). Untuk mendeteksi ada atau tidaknya Multikolinearitas didalam model regresi adalah dengan melihat nilai tolerance dan Varian Inflation Factor (VIF). Jika nilai semua tolerance lebih besar dari 0,01 atau memiliki nilai VIF kurang dari 10, maka model dikatakan bebas gejala Multikolinearitas.

Tabel 5. Hasil Uji Multikolinearitas

\begin{tabular}{lcc}
\hline \multicolumn{1}{c}{ Variabel } & Tolerance & VIF \\
\hline Modal $\left(\mathrm{X}_{1}\right)$ & .859 & 1.164 \\
Jam Kerja $\left(\mathrm{X}_{2}\right)$ & .859 & 1.164 \\
\hline & Sumber : SPSS &
\end{tabular}

Berdasarkan hasil output pada Tabel 5 diketahui bahwa, nilai tolerance semua variable independen lebih besar dari 0,01 dan nilai VIF semua variabel independen lebih kecil dari 10,00 maka dapat disimpulkan bahwa tidak terjadi multikolinearitas.

\section{Uji Heterokedatisitas}

Uji ini digunakan untuk mengetahui variabel penggangu dalam persamaan regresi mempunyai varians yang sama atau tidak. Jika mempunyai varians yang sama, berarti tidak terdapat heteroskeditasitas, sedangkan mempunyai varians yang tidak sama maka terdapat heterokedatisitas. Berikut hasil output dari uji heterokedatisitas :

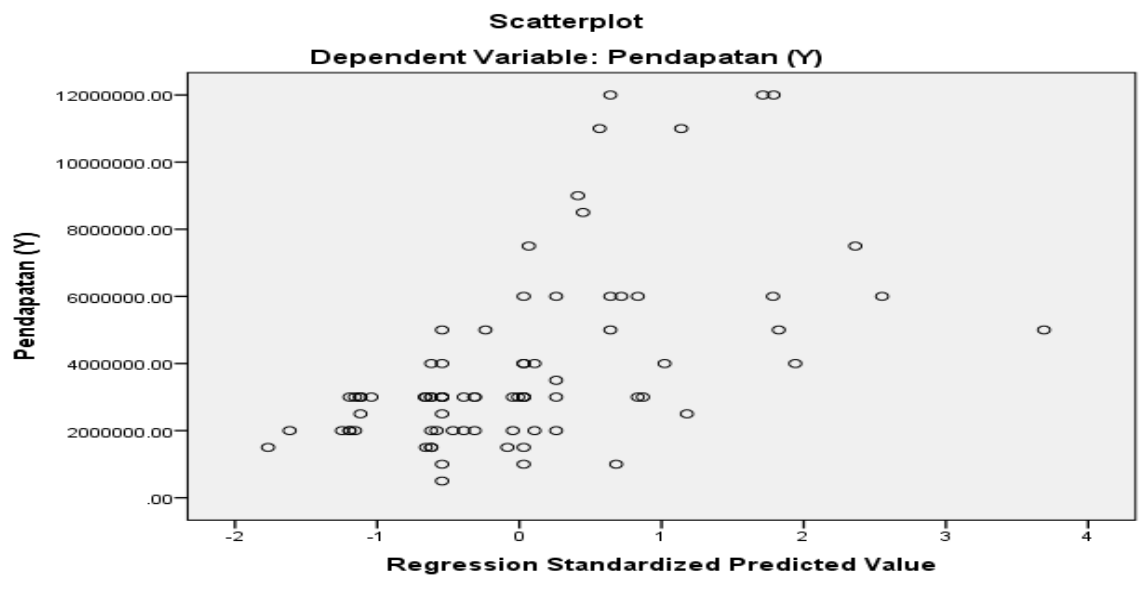

Gambar 1. Hasil Uji Heterokedatisitas

Sumber : SPSS

Berdasarkan grafik scatterplot di atas dapat terlihat bahwa titik-titik menyebar pada nilai 0 sumbu horizontal (regression standardized predicted value) dan pada nilai 0 sumbu vertikal (regression stundentized residual) serta menyebar secara acak dan tidak membentuk pola tertentu. Dari hasil analisis grafik scatterplot di atas dapat disimpulkan bahwa model regresi tidak terjadi gejala heteroskedastisitas.

\section{Uji Autokorelasi}

Uji ini adalah untuk mengetahui apakah dalam persamaan regresi terdapat kondisi serial atau tidak antara variable pengganggu. Oleh karena itu dalam penelitian ini dilakukan uji autokorelasi menggunakan metode uji Durbin Watson.

Tabel. 6 Hasil Uji Autokorelasi Durbin Watson Model Summary ${ }^{\mathrm{b}}$

\begin{tabular}{|c|c|c|c|c|c|c|c|c|c|c|}
\hline \multirow[t]{2}{*}{ Model } & \multirow[t]{2}{*}{$\mathrm{R}$} & \multirow[t]{2}{*}{ R Square } & \multirow{2}{*}{$\begin{array}{l}\text { Adjusted R } \\
\text { Square }\end{array}$} & \multirow{2}{*}{$\begin{array}{l}\text { Std. Error of the } \\
\text { Estimate }\end{array}$} & \multicolumn{5}{|c|}{ Change Statistics } & \multirow[t]{2}{*}{ Durbin-Watson } \\
\hline & & & & & $\begin{array}{l}\text { R Square } \\
\text { Change }\end{array}$ & $\begin{array}{c}\mathrm{F} \\
\text { Change }\end{array}$ & $\begin{array}{c}\mathrm{df} \\
1\end{array}$ & $\begin{array}{l}\mathrm{df} \\
2\end{array}$ & $\begin{array}{l}\text { Sig. F } \\
\text { Change }\end{array}$ & \\
\hline 1 & $.552 \mathrm{a}$ & .305 & 287 & 2232790.7 & .305 & 16.887 & 2 & 77 & .000 & 1.807 \\
\hline
\end{tabular}


Berdasarkan Tabel 6 ditunjukan bahwa nilai dari Durbin Waston sebesar 1,807 dan di tabel untuk observasi sebanyak $80(\mathrm{n}=80)$ dengan jumlah variable bebas $(\mathrm{X})$ sebanyak $2(\mathrm{k}=2)$ diperoleh nilai $\mathrm{dL}=$ 1,5859 serta nilai $\mathrm{dU}=1,6882$ kesimpulan uji autokorelasi adalah dengan syarat $\mathrm{dL}<\mathrm{d}<4$-dU maka $1,5859<1,807<2,3118$ jadi dapat diambil kesimpulan tidak terjadi autokorelasi.

\section{Hasil analisis regresi linear berganda}

Model analisis yang digunakan dalam penelitian ini adalah regresi linear berganda, yaitu untuk menganalisis pengaruh faktor modal dan jam kerja terhadap pendapatan pedagang di Pasar Gulingan, Kecamatan Mengwi, Kabupaten Badung. Analisis regresi linear berganda juga digunakan untuk menentukan besarnya pengaruh variabel bebas terhadap variabel terikat, dengan sampel sebanyak 80 responden. Adapun rangkuman dari hasil pengolahan data-data dan penjelasannya dapat kita lihat pada Tabel 7 berikut :

Tabel 7. Hasil Perhitungan Regresi Linear Berganda Metode Full Regresssion

\begin{tabular}{|c|c|c|c|c|c|}
\hline \multirow[b]{2}{*}{ Model } & \multicolumn{2}{|c|}{ Unstandardized Coefficients } & $\begin{array}{l}\text { Standardized } \\
\text { Coefficients }\end{array}$ & \multirow[b]{2}{*}{$\mathrm{t}$} & \multirow[b]{2}{*}{ Sig. } \\
\hline & $\mathrm{B}$ & Std. Error & Beta & & \\
\hline $1 \quad$ (Constant) & -3007252.008 & 1714619.198 & & -1.754 & .083 \\
\hline Modal $\left(\mathrm{X}_{1}\right)$ & .111 & .038 & .297 & 2.900 & .005 \\
\hline $\operatorname{Jam} \operatorname{Kerja}\left(\mathrm{X}_{2}\right)$ & 27933.351 & 7800.014 & .367 & 3.581 & .001 \\
\hline
\end{tabular}

berikut :

Berdasarkan Tabel 7 di atas, maka diperoleh persamaan model regresi linear berganda sebagai

$$
Y=-3.007 .252,008+0,111 X_{1}+27.933,351 X_{2}
$$

Berdasarkan persamaan regresi linear di atas, maka dapat dijelaskan koefisien regresinya masingmasing sebagai berikut :

1. Koefisien regresi $\left(b_{1}\right)$ untuk variabel modal $\left(X_{1}\right)$, diperoleh sebesar 0,111 (bertanda positif), artinya hubungan variabel bebas dengan variabel terikat adalah searah atau setiap penambahan modal sebesar satu rupiah, maka pendapatan pedagang di Pasar Gulingan, Kecamatan Mengwi, Kabupaten Badung akan meningkat rata-rata sebesar 0,111 rupiah setiap bulan dengan asumsi variabel lainnya adalah konstan.

2. Koefisien regresi $\left(b_{2}\right)$ untuk variabel jam kerja $\left(X_{2}\right)$ diperoleh sebesar 27.933,351 (bertanda positif), artinya hubungan variabel bebas dengan variabel terikat adalah searah atau setiap jam kerja bertambah 1 jam, maka pendapatan pedagang di Pasar Gulingan, Kecamatan Mengwi, Kabupaten Badung akan meningkat rata-rata sebesar Rp 27.933,351 setiap bulan dengan asumsi variabel lainnya adalah konstan.

\section{Uji hipotesis pertama (Uji t)}

Uji hipotesis secara parsial atau uji t digunakan untuk menguji pengaruh masing-masing variabel bebas $(\mathrm{X})$ terhadap variabel terikat $(\mathrm{Y})$. Dengan melakukan pengujian secara parsial maka dapat diketahui signifikan tidaknya pengaruh masing-masing variabel bebas terhadap pendapatan pedagang di Pasar Gulingan, Kecamatan Mengwi, Kabupaten Badung. Pengujian dengan menggunakan uji t dilakukan dengan cara membandingkan nilai $\mathrm{t}$ tabel dengan nilai $\mathrm{t}$ hitung atau membandingkan signifikannya pada tarap nyata $0,05(5 \%)$. Nilai t tabel adalah sebesar 1,665. Berdasarkan Tabel 7 dapat diketahui besarnya nilai t hitung dan tingkat signifikannya antara lain sebagai berikut :

1. Pengaruh modal $\left(\mathrm{X}_{1}\right)$ terhadap pendapatan pedagang di Pasar Gulingan, Kecamtan Mengwi, Kabupaten Badung.

Berdasarkan Tabel 7 dapat diketahui bahwa t hitung diperoleh sebesar 2,900 sedangkan t tabel dengan derajat 0,05 , diperoleh sebesar 1,665. Oleh karena itu, t hitung lebih besar dari t tabel $(2,900>1,665)$ dan singnifikannya sebesar 0,005, lebih kecil dari 0,05 maka Ho ditolak Ha diterima, berarti modal berpengaruh nyata positif terhadap pendapatan pedagang di Pasar Gulingan, Kecamtan Mengwi, Kabupaten Badung. Hal ini berarti semakin besar modal usaha maka kemungkinan untuk mendapatkan pendapatan semakin besar. Hasil tersebut mendukung penelitian sebelumnya yang dilakukan oleh Anggraini (2019), Mithaswari (2018), Irawan (2017) dan Prastyadewi (2016) mempunyai kesimpulan yang sama yaitu modal berpengaruh positif dan signifikan terhadap pendapatan pedagang. Hasil tersebut sesuai dengan hipotesis yang menyatakan bahwa modal memiliki pengaruh positif dan nyata terhadap pendapatan pedagang di Pasar Gulingan, Kecamatan Mengwi, Kabupaten Badung.

2. Pengaruh jam kerja $\left(\mathrm{X}_{2}\right)$ terhadap pendapatan pedagang di Pasar Gulingan, Kecamtan Mengwi, Kabupaten Badung.

Berdasarkan Tabel 7 di atas diketahui $t$ hitung diperoleh sebesar 3,581 sedangkan $t$ tabel dengan derajat 0,05 diperoleh sebesar 1,665. Oleh karena itu t hitung lebih besar dari t tabel $(3,581>1,665)$ dan signifikannya adalah 0,001 lebih kecil 0,05 maka Ho ditolak Ha diterima berarti jam kerja berpengaruh nyata positif terhadap pendapatan pedagang di Pasar Gulingan Kecamtan Mengwi Kabupaten Badung. 
Ini Berarti bahwa semakin lama jam kerja atau operasionalnya maka semakin tinggi pula kesempatan untuk memperoleh pendapatan yang tinggi. Penelitian ini mendukung hasil penelitian yang dilakukan oleh Anggraini (2019), Irawan (2017) dan Prastyadewi (2016), yang menyatakan bahwa jam kerja berpengaruh positif dan nyata terhadap pendapatan pedagang. Hasil tersebut sesuai dengan hipotesis yang menyatakan bahwa jam kerja memiliki pengaruh positif dan nyata terhadap pendapatan pedagang di Pasar Gulingan, Kecamatan Mengwi, Kabupaten Badung.

\section{Uji hipotesis kedua (Uji F)}

Uji $\mathrm{F}$ adalah alat statistik yang digunakan untuk menentukan pengaruh secara serempak atau simultan variabel-variabel bebas yaitu modal dan jam kerja terhadap variabel terikat yaitu pendapatan pedagang di Pasar Gulingan, Kecamatan Mengwi, Kabupaten Badung. Derajat kepercayaan yang digunakan adalah 0,05. Apabila nilai $\mathrm{F}$ hitung lebih besar dari nilai $\mathrm{F}$ tabel, maka hipotesis alternatif, yang menyatakan bahwa semua variabel bebas secara simultan berpengaruh nyata terhadap variabel terikat. Untuk analisisnya dari output SPSS dapat dilihat dari tabel Model Summary, lebih jelasnya dapat dilihat pada Tabel 8 sebagai berikut :

Tabel 8. Hasil Perhitungan Regresi Linear Berganda Model Summary

\begin{tabular}{llrrrrrrrr}
\hline & & & & & \multicolumn{4}{c}{ Change Statistics } \\
\cline { 5 - 9 } Mo & & $\mathrm{R}$ & Adjusted & Std. Error of & R Square & & & \multicolumn{2}{c}{ Sig. F } \\
del & $\mathrm{R}$ & Square & R Square & the Estimate & Change & F Change & df1 & df2 & Change \\
\hline 1 & $.552^{\mathrm{a}}$ & .305 & .287 & 2232790.7 & .305 & 16.887 & 2 & 77 & .000 \\
\hline
\end{tabular}

Sumber : SPSS

Berdasarkan Tabel 8 diperoleh nilai $\mathrm{F}$ hitung sebesar 16.887 sedangkan $\mathrm{F}$ tabel dengan tarif nyata 0,05 adalah sebesar 3,12 berarti $\mathrm{F}$ hitung lebih besar dari $\mathrm{F}$ tabel $(16,887>3,12)$ dan signifikannya adalah 0,000 lebih kecil dari tarif nyata $0,05(0,000<0,05)$ maka Ho ditolak dan Ha diterima. Dengan demikian dapat dikatakan bahwa variabel-variabel bebas yaitu modal dan jam kerja berpengaruh nyata (signifikan) secara simultan terhadap variabel terikat yaitu pendapatan pedagang di Pasar Gulingan, Kecamatan Mengwi, Kabupaten Badung. Penelitian ini sesuai dengan penelitian yang dilakukan oleh Anggraini, 2019 yang berjudul "Pengaruh Faktor Modal, Jam Kerja Dan Lama Usaha Terhadap Pendapatan Usaha Mikro Kecil Menengah (Studi Kasus Pada Pedagang Pasar Pagi Prumdam II Kota Bengkulu). Hasil penelitian ini menunjukkan bahwa variabel modal dan jam kerja berpengaruh secara signifikan terhadap pendapatan pedagang. Dengan demikian hipotesis ketiga benar bahwa secara serempak modal dan jam kerja berpengaruh nyata secara simultan terhadap pendapatan pedagang di Pasar Gulingan Kecamatan Mengwi Kabupaten Badung.

\section{Koefisien Determinasi $\left(\mathbf{R}^{2}\right)$.}

Berdasarkan Tabel 8 besarnya pengaruh variabel-variabel bebas terhadap variabel terikat secara serempak dapat diketahui dari besarnya nilai koefisien determinasinya $\left(R^{2}\right)$. Pada Tabel 8 diketahui $R^{2}$ adalah sebesar 0,305 berarti bahwa variabel-variabel bebas (modal dan jam kerja) tersebut secara bersamasama memberikan kontribusi sebesar 30,5 persen terhadap pendapatan pedagang di Pasar Gulingan Kecamatan Mengwi Kabupaten Badung. Sedangkan sisanya sebesar 69,6 persen, dipengaruhi oleh faktor lain yang tidak dijelaskan dalam model ini. Berdasarkan uraian tersebut dapat diketahui bahwa hasil nilai koefisien mendekati 0 artinya variabel-variabel bebas yaitu modal dan jam kerja memberikan informasi amat terbatas yang dibutuhkan untuk memprediksi variasi variabel terikat.

\section{PENUTUP}

\section{Simpulan}

Berdasarkan hasil dan pembahasan pada bab sebelumnya, maka dapat dibuat simpulan sebagai berikut:

1. Modal berpengaruh positif dan nyata secara parsial terhadap pendapatan pedagang di Pasar Gulingan Kecamatan Mengwi Kabupaten Badung.

2. Jam kerja berpengaruh positif dan nyata secara parsial terhadap pendapatan pedagang di Pasar Gulingan Kecamatan Mengwi Kabupaten Badung.

4. Modal dan jam kerja secara bersama-sama atau simultan berpengaruh nyata terhadap pendapatan pedagang di Pasar Gulingan Kecamatan Mengwi Kabupaten Badung. 


\section{Saran}

Berdasarkan penelitian dan hasil analisis yang diperoleh, maka dapat disampaikan saran-saran sebagai berikut :

1. Bagi Pedagang Pasar

Modal dan jam kerja termasuk faktor-faktor yang mempengaruhi pendapatan. Faktor modal dan jam kerja sangat memberikan pengaruh terhadap besar kecilnya pendapatan seorang pedagang. Hal ini diperkuat dengan adanya modal dan jam kerja dalam berjualan akan meningkatkan pendapatan pedagang. Sehingga implikasi dalam penelitian ini bagi pedagang di Pasar Gulingan, Kecamatan Mengwi, Kabupaten Badung dalam meningkatkan pendapatan, maka harus menambahkan modal usahanya dan menambah jam kerja dalam berjualan.

2. Bagi Peneliti Lanjutan

Peneliti selanjutnya diharapkan menggunakan periode pengamatan yang lebih panjang dengan tujuan memperoleh hasil yang lebih baik. Selain itu diharapkan memasukkan variabel lain yang belum dimasukkan dalam model penelitian.

\section{DAFTAR PUSTAKA}

Anggraini. W. (2019). Pengaruh Faktor Modal, Jam Kerja Dan Lama Usaha Terhadap Pendapatan UMKM Kota Bengkulu. Skripsi, Fakultas Ekonomi Dan Bisnis Islam Institut Agama Islam Negeri Bengkulu.

Ayuningsasi, A.A. (2013). Analisis Pendapatan Pedagang Sebelum Dan Sesudah Program Revitalisasi Pasar Tradisional Di Kota Denpasar (Studi Kasus Pasar Sudha Merta Desa Sidakarya). Piramida, 7(1). ISSN 1907-3275.

Chris M. (2006). Labour Market Adjustment to Indonesia's Economic Crisis: Context, Trends and Implications. Bulletin of Indonesian Economic Studies, 36:1, 105-136

Guna, J. (2015). Analisis Efektivitas Revitalisasi Pasar Tradisional dan Dampaknya Terhadap Pengelolaan Pasar, Jumlah Pengunjung, dan Pendapatan Pedagang. E-Journal Ekonomi Pembangunan Universitas Udayana. Vol. 5, No. 1, pp. 142-143

Hentiani, T. (2011). Analisis Faktor-faktor Yang Mempengaruhi Pendapatan Pedagang Informal Di Pajak Sentral Medan. Tesis. Universitas Sumatra Utara.

Ika Prasetyadewi Made. (2016). Analisis Pendapatan Pedagang Pasar Seni Sukawati. Jurnal Fakultas Ekonomi dan Bisnis Unversitas Udayana (Unud), Bali, Indonesia

Irawan, H. (2017). Analisis Variabel Yang Mempengaruhi Pendapatan Pedagang Di Pasar Kreneng Kota Denpasar. Jurnal. Fakultas Ekonomi dan Bisnis Universitas Udayana, Bali

Maharani D. P. (2016). Pengaruh Modal Sendiri dan Lokasi Usaha Terhadap Pendapatan Usaha Mikro Kecil Menengah (UMKM) di Kabupaten Tabanan (Modal Pinjaman sebagai Variabel Intervening). Jurnal Ekonomi Kuantitatif Terapan. Vol. 9, No. 2, Pp. 143-144

Mithaswari, D. (2018). Analisis Faktor-Faktor Yang Mempengaruhi Pendapatan Pedagang Di Pasar Seni Guwang. Jurnal Fakultas Ekonomi dan Bisnis Unversitas Udayana (Unud), Bali, Indonesia

Nugraha, L.A. (2011). Pengaruh Modal Usaha, Tingkat Pendidikan, dan Sikap Kewirausahaan terhadap Pendapatan Usaha Pengusaha Industri Kerajinan Perak Di Desa Sodo Kecamatan Paliyan Kabupaten Gunung Kidul. Skripsi: Universitas Negeri Yogyakarta

Prathiwa, P. (2016). Pengaruh Revitalisasi Pasar Tradisional Dan Sumber Daya Pedagang Terhadap Kinerja Pedagang Pasar Di Kota Denpasar. E-Journal Ekonomi Pembangunan Universitas Udayana. Vol. 5, No. 4, pp. 467-468

Sudrajat, A. 2014). Analisis Faktor-faktor yang Memempengaruhi Pendapatan Pedagang Muslim (Studi pada Pedagnag Sayuran Pasar Jagasatru Cirebon). Jurnal ADDIN, Vol.8, No.1: 107-134

Suroto. (2011). Strategi pembangunan dan perencanaan Kesempatan Kerja. Yogyakarta: Gajahmada University.

Susila, A. (2014). Analisis Perbedaan Rata-Rata Pendapatan Pedagang Acung Pinggir Pantai Di Kecamatan Kuta Kabupaten Badung. E-Journal Ekonomi Pembangunan Universitas Udayana. Vol. 2, No. 6, pp. 286-287

Titin. (2014). Analisa Faktor Luas Lahan Dan Tenaga Kerja Terhadap Tingkat Pendapatan Petani Jagung Di Desa Dadapan. Skripsi. Fakultas Ekonomi Universitas Islam Lamongan, Lamongan. 